\title{
Simultaneous Detection of Multiple Transgenes for Genetically-Modified Mouse Strains
}

\author{
Hatsumi NAKATA, Tomomi HASHIMOTO, Yukiko SEKI, \\ Kazuyuki MEKADA, Yuichi OBATA, and Atsushi YOSHIKI \\ Experimental Animal Division, RIKEN BioResource Center, \\ 3-1-1 Koyadai, Tsukuba, Ibaraki 305-0074, Japan
}

\begin{abstract}
Recent advances in the genetic manipulation of mice have enabled us to generate transgenic and knockout mice. However, it is not easy to maintain these genetically-modified mice with the high-quality necessary to meet both scientific and legal requirements. RIKEN $\mathrm{BRC}$ has collected various transgenic, knockout, and conditional knockout mice. To examine the genetic modifications in these strains quickly and thoroughly, we established a simultaneous PCR test to detect multiple transgenes. We have called this, the "KO-survey". The PCR condition was optimized to detect neo, puro, pgk-neo, lacZ, and HSVtk-neo in set I, and hyg, IRES, cre, flp, and Gfp in set II. This "KO-survey" is useful for providing users with mouse strains of the highest genetic quality and accurate information on their genetic modifications.
\end{abstract}

Key words: Cartagena Law, genotyping, knockout mice

Mice are one of the most important animal models in life sciences $[2,6,26]$. Recent advances in the genetic manipulation of mice using various technologies and systems have enabled us to generate transgenic and knockout mice with precise control of the gene expression $[4,19,25]$. The recombinant gene constructs designed for genetic modifications are becoming increasingly complex with multiple components, such as promoters, selectable markers, visualizing reporters, recombinase genes, and their target sequences $[1,15,18$, 19]. Recently, multiple crosses of transgenic and knockout mice have become common procedures in the functional analyses $[16,18,23]$. Therefore, it has become necessary for a mouse resource center to thoroughly examine these multiple transgenes, whether or not they are kept as originally designed, and when new strains are deposited.

RIKEN BioResource Center (BRC) was established in 2001 as a comprehensive biological resource center in Japan. Our primary mission is to collect, preserve, conduct quality control, and distribute mouse strains developed mainly by Japanese scientists. We have been acting as the core facility of the mouse resources in the National BioResource Project (NBRP) promoted by the Ministry of Education, Culture, Sports, Science and Technology (MEXT) of Japan since 2002. The mouse strain collection includes various genetically-modified strains such as transgenic, knockout, and conditional knockout mice [26].

In Japan, all handling and activity with genetically-

(Received 14 January 2009 / Accepted 26 March 2009)

Address corresponding: A. Yoshiki, Experimental Animal Division, RIKEN BioResource Center, 3-1-1 Koyadai, Tsukuba, Ibaraki 305-0074, Japan 
Table 1. Various transgenes used in the genetically-modified mouse strains at the RIKEN BRC according to depositor's information provision

\begin{tabular}{|c|c|c|c|c|c|c|}
\hline \multirow[b]{2}{*}{ Name of the transgene } & \multirow[b]{2}{*}{ Puropose/Function } & \multirow[b]{2}{*}{ Species origin } & \multicolumn{2}{|c|}{ Number of transegenes in } & \multirow[b]{2}{*}{ Total } & \multirow[b]{2}{*}{$\%$} \\
\hline & & & $\begin{array}{l}\text { Knockout } \\
\text { mice }\end{array}$ & $\begin{array}{l}\text { Transgenic } \\
\text { mice }\end{array}$ & & \\
\hline $\begin{array}{l}\text { neomycin resistance gene } \\
\text { (neo) }\end{array}$ & $\begin{array}{l}\text { Drug-resistance selec- } \\
\text { tion marker }\end{array}$ & E. coli & 285 & 6 & 291 & 28.6 \\
\hline $\begin{array}{l}\text { Green fluorescence protein } \\
(G f p)\end{array}$ & Fluorescent reporter & Jellyfish & 21 & 208 & 229 & 22.5 \\
\hline $\begin{array}{l}\text { phosphoglycerate kinase and } \\
\text { neomycin resistance fusion } \\
\text { gene cassette ( } p g k \text {-neo) }\end{array}$ & $\begin{array}{l}\text { Promoter and selection } \\
\text { marker }\end{array}$ & Mouse and E. coli & 168 & 4 & 172 & 16.9 \\
\hline beta galactosidase gene (lacZ) & Histochemical reporter & E. coli & 108 & 60 & 168 & 16.5 \\
\hline Cre recombinase gene ( $\mathrm{cre}$ ) & $\begin{array}{l}\text { Recombinase for condi- } \\
\text { tional knockout }\end{array}$ & Phage P1 & 16 & 44 & 60 & 5.9 \\
\hline $\begin{array}{l}\text { HSV thymidine kinase and } \\
\text { neomycin resistance fusion } \\
\text { gene cassette (HSVtk-neo) }\end{array}$ & $\begin{array}{l}\text { Promoter and selection } \\
\text { marker }\end{array}$ & $\begin{array}{l}\text { Herpes simplex virus } \\
\text { (HSV) and } E \text {. coli }\end{array}$ & 46 & 0 & 46 & 4.5 \\
\hline $\begin{array}{l}\text { Internal Ribosome Entry Site } \\
(I R E S)\end{array}$ & $\begin{array}{l}\text { Internal Ribosome En- } \\
\text { try Site }\end{array}$ & $\begin{array}{l}\text { Encephalomyocardi- } \\
\text { tis virus (EMCV) }\end{array}$ & 18 & 21 & 39 & 3.8 \\
\hline $\begin{array}{l}\text { puromycin resistance gene } \\
\text { (puro) }\end{array}$ & $\begin{array}{l}\text { Drug-resistance selec- } \\
\text { tion marker }\end{array}$ & $\begin{array}{l}\text { Streptomyces alboni- } \\
\text { ger }\end{array}$ & 1 & 5 & 6 & 0.6 \\
\hline Flipase gene $(f l p)$ & $\begin{array}{l}\text { Recombinase for condi- } \\
\text { tional knockout }\end{array}$ & Yeast & 1 & 4 & 5 & 0.5 \\
\hline \multirow[t]{3}{*}{$\begin{array}{l}\text { hygromycin resistance gene } \\
\text { (hyg) }\end{array}$} & $\begin{array}{l}\text { Drug-resistance selec- } \\
\text { tion marker }\end{array}$ & E. coli & 3 & 0 & 3 & 0.3 \\
\hline & \multicolumn{2}{|c|}{ Total number of transgenes } & 667 & 352 & 1,019 & 100.0 \\
\hline & & Number of strains & 512 & 310 & 822 & \\
\hline
\end{tabular}

modified animals must be conducted in compliance with all applicable laws, including the Law Concerning the Conservation and Sustainable Use of Biological Diversity Through Regulations on the Use of Living Modified Organisms, the so-called "Cartagena Law". Under this law a scientist and her/his organization must provide accurate information on the genetic modification when they transport genetically-modified mice to another organization. To continue operation of the NBRP core facility of mouse resources, we need to thoroughly examine the genetic modifications of the genetically-modified strains and maintain the highest genetic quality that meets both the scientific and legal requirements. For this purpose, we have recently established a simultaneous detection PCR test for multiple transgenes, designated the "KO-survey", as part of our genetic quality control program.
For the development of the KO-survey, first we examined the information provided from the depositor scientists of 822 genetically-modified (512 knockout and 310 transgenic) strains carrying 1,019 transgenes. As listed in Table 1, we have selected ten representative transgenes, neo, Gfp, pgk-neo, lacZ, cre, HSVtk-neo, IRES, puro, $f p$, and hyg, to be examined in the KO-survey PCR. The number of each transgene in the knockout and transgenic strains was counted and its frequency expressed as a percentage (\%). The use of puro, flp, and hyg is expected to increase in the near future because of an anticipated rapid increase in the generation of conditional knockout mice [5], and they were included in the KO-survey PCR, even though they are currently minor components with frequencies of less than $1 \%$. The CAGpromoter is a widely used as a transgenic component [20], but is not included in Table 1. Transgenes with 
Table 2. List of primers for the KO-survey PCR

\begin{tabular}{|c|c|c|c|c|c|}
\hline $\begin{array}{l}\text { Set } \\
\text { name }\end{array}$ & Gene name & $\begin{array}{l}\text { Primer sequence } \\
\text { (upper; forward primer, lower; reverse primer) }\end{array}$ & $\begin{array}{l}\text { Product } \\
\text { size }\end{array}$ & $\begin{array}{c}\text { GenBank } \\
\text { accession No. }\end{array}$ & References \\
\hline \multirow[t]{10}{*}{ Set I } & neo & 5'-TGGATTGCACGCAGGTTCTC-3' & 617 bp & NC_008460 & [7] \\
\hline & & 5'-CGGCCACAGTCGATGAATCC-3' & & & \\
\hline & puro & 5'-ATGACCGAGTACAAGCCCAC-3' & $470 \mathrm{bp}$ & M25346 & [3], http://www.jax.org/ \\
\hline & & 5'-GGCACCCCGGCGCGCTCGGC-3' & & & This study \\
\hline & pgk-neo* & 5'-CGCGCCACCTTCTACTCCTC-3' & 393 bp & NT_039706 (pgk) & This study \\
\hline & & 5'-GCAATCCATCTTGTTCAATGGCC-3' & & AF335419 (pgk-neo) & [11] \\
\hline & lac $Z$ & 5'-ATCCTCTGCATGGTCAGGTC-3' & $315 \mathrm{bp}$ & NC_011750 & [3], http://www.jax.org/ \\
\hline & & 5'-CGTGGCCTGATTCATTCC-3' & & & \\
\hline & HSV $t k-n e o^{*}$ & 5'-CAAACCCCGCCCAGCGTCTTGTC-3' & $163 \mathrm{bp}$ & $\mathrm{X} 14112(\mathrm{HSV} t k)$ & This study \\
\hline & & 5'-GCAATCCATCTTGTTCAATGGCC-3' & & U43612 (HSVtk-neo) & [11] \\
\hline \multirow[t]{10}{*}{ Set II } & hyg & 5'-GCCTGACCTATTGCATCTCC-3' & $723 \mathrm{bp}$ & V01499 & This study \\
\hline & & 5'-CGGCGAGTACTTCTACACAG-3' & & & \\
\hline & $I R E S^{* *}$ & 5'-gggatccgССССТСТСССТССССССССССТАACG-3' & $597 \mathrm{bp}$ & X74312 & This study \\
\hline & & 5'-gagatcTGTGGCCATATTATCATCGTGTTTTTC-3' & & & \\
\hline & cre & 5'-TCGATGCAACGAGTGATGAG-3' & $482 \mathrm{bp}$ & NC_005856 & {$[10]$} \\
\hline & & 5'-TTCGGCTATACGTAACAGGG-3' & & & \\
\hline & flp & 5'-CTGCTTCTTCCGATGATTCG-3' & 372 bp & U46493 & [9] \\
\hline & & 5'-CACCACCTAAGGTGCTTGTTC-3' & & & \\
\hline & Gfp & 5'-AAGTTCATCTGCACCACCG-3' & 173 bp & U55763 & [3], http://www.jax.org/ \\
\hline & & 5'-TCСТTGAAGAAGATGGTGCG-3' & & & \\
\hline
\end{tabular}

*Forward primers for $p g k$-neo and HSV tk-neo were specific to mouse $p g k$ and HSVtk, respectively. Reverse primers for $p g k$ - $n e o$ and HSV $t k$ $n e o$ were common and specific to neo. Therefore, the primer set for $p g k$-neo does not amplify the endogenouse mouse $p g k$. $* *$ Primers for IRES contain addtitional sequences as indicated by small letters for cloning and adjustment of the product size (597 bp) to make it appropriate for the KO-survey PCR.

CAG-promoter are usually integrated as multiple transgenes in a tandem arrangement, and may result in multiple PCR fragments of various sizes (data not shown). Therefore, we detect the transgenes with CAG-promoter separately in a single PCR test, not included in the KO-survey PCR.

Next, we tried to set up a multiplex PCR that simultaneously detects the ten transgenes in minimal reactions. Primer sequences were retrieved from public databases [3], other publications $[7,9,11]$ or were originally designed for this study (Table 2). The following mouse strains carrying specific transgenes were used to extract genomic DNA for the optimization of the multiplex PCR: B6.Cg-TgTn(sb-lacZ,GFP)IF2Jtak (RBRC01652) carrying neo, lacZ, pgk-neo, IRES and Gfp [14], C57BL/6Tg(CAG-FLPe)36Ito (RBRC01834) carrying puro [13], CNR CP carrying HSVtk-neo (an unpublished strain kindly provided by Dr. T. Yagi, Osaka University),

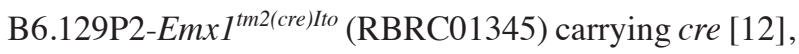

C57BL/6N-Tg(EIF1A-flp)66Mim (RBRC01252) carrying $f l p$ [24], FVB.129P2-Nf2 $2^{\text {tmlGth }}$ (RBRC01678) carrying hyg [10], and C57BL/6JJcl (CLEA Japan, Inc., Tokyo, Japan) for wild-type DNA. Genomic DNAs were extracted from tail tips by automated DNA isolators (NA-2000 and PI-200, Kurabo, Kyutaro-machi, Osaka, Japan) with a final concentration of $100-300 \mathrm{ng} / \mu 1$. Three microliters of genomic DNA was used as the template. A mixture solution of the same volume of genomic DNA from the above genetically-modified strains was used as a positive control for the KO-survey PCR.

It was found that two sets of multiplex PCR reactions are enough to survey all the transgenes. We optimized the PCR conditions with a Biometra Thermocycler (Goettingen, Germany) to simultaneously amplify five transgenes in one tube, such as neo, puro,pgk-neo, lacZ, and HSVtk-neo in set I using LA-Taq with GC-I buffer (Takara, Kyoto, Japan), and hyg, IRES, cre, flp, and Gfp in set II using Multiplex PCR Kit (Qiagen, Hilden, Ger- 
Table 3. Components of reaction mixture for the KO-survey PCR

\begin{tabular}{|c|c|c|c|}
\hline \multicolumn{2}{|c|}{ Set I (Total volume $20 \mu \mathrm{l}$ ) } & \multicolumn{2}{|c|}{ Set II (Total volume $20 \mu 1$ ) } \\
\hline $2 \times$ GC-I Buffer & $10.0 \mu 1$ & $2 \times$ Master Mix & $10.0 \mu 1$ \\
\hline $2.5 \mathrm{mM}$ dNTP & $2.0 \mu 1$ & & \\
\hline Distilled water & $3.8 \mu 1$ & Distilled water & $6.0 \mu 1$ \\
\hline Mixed primers solution* & $1.0 \mu 1$ & Mixed primers solution* & $1.0 \mu 1$ \\
\hline neo & $5 \mu \mathrm{M}, 5 \mu \mathrm{M}$ & hyg & $15 \mu \mathrm{M}, 15 \mu \mathrm{M}$ \\
\hline puro & $2.5 \mu \mathrm{M}, 2.5 \mu \mathrm{M}$ & IRES & $5 \mu \mathrm{M}, 5 \mu \mathrm{M}$ \\
\hline pgk-neo & $10 \mu \mathrm{M}, 10 \mu \mathrm{M}$ & cre & $5 \mu \mathrm{M}, 5 \mu \mathrm{M}$ \\
\hline lacZ & $15 \mu \mathrm{M}, 15 \mu \mathrm{M}$ & $f l p$ & $15 \mu \mathrm{M}, 15 \mu \mathrm{M}$ \\
\hline HSV tk-neo & $20 \mu \mathrm{M}, 15 \mu \mathrm{M}$ & Gfp & $10 \mu \mathrm{M}, 10 \mu \mathrm{M}$ \\
\hline Template DNA & $3.0 \mu 1$ & Template DNA & $3.0 \mu 1$ \\
\hline LA Taq (5 units $/ \mu 1$ ) & $0.2 \mu 1$ & & \\
\hline
\end{tabular}

*Each mixed primer solution contains forward and reverse primers of each transgene. The final concentration of each primer (forward, reverse) is indicated.

A

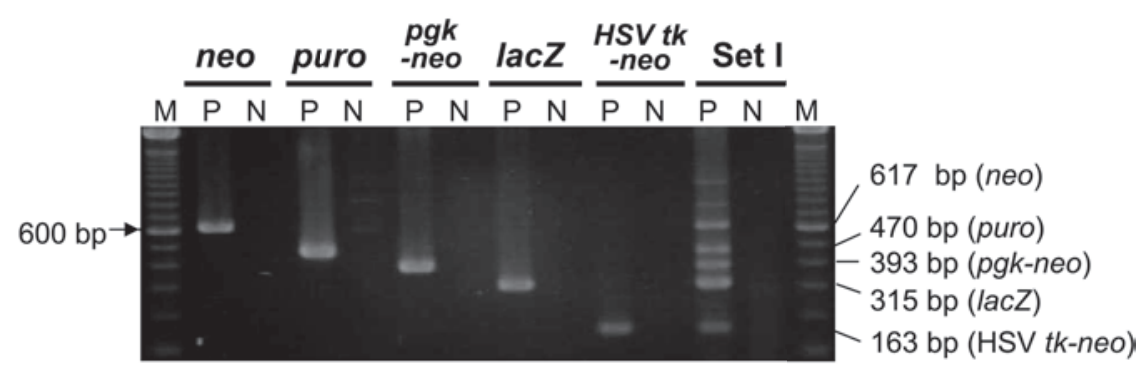

B

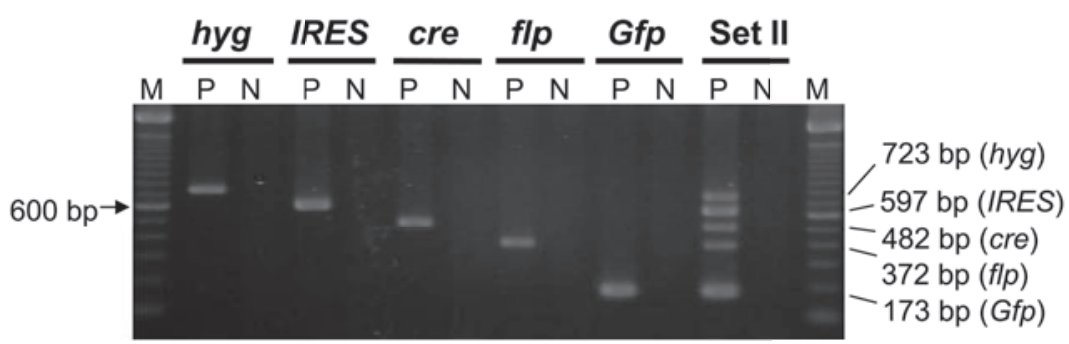

Fig. 1. Results of KO-survey PCR using positive control DNA. (A) neo, puro, pgk-neo, lacZ, and HSVtkneo: Each transgene was amplified with a single primer set by using a positive control $(\mathrm{P})$ and C57BL/6JJcl DNA (N). Set I: Multiple transgenes were amplified simultaneously by the KOsurvey PCR set I using a positive control (P) and C57BL/6JJcl DNA (N). Lanes M: DNA Marker (100 bp ladder; Invitrogen Japan K.K., Tokyo). (B) hyg, IRES, cre, fp, and Gfp: Each transgene was amplified with a single primer set by using a positive control (P) and C57BL/6JJcl DNA (N). Set II: Multiple transgenes were amplified simultaneously by the KO-survey PCR set II using a positive control (P) and C57BL/6JJcl DNA (N). Lanes M: DNA Marker (100 bp ladder).

many) (Table 3). The PCR temperatures and cycling for sets I and II are as follows: set I has an initial heating at $94^{\circ} \mathrm{C}$ for $180 \mathrm{~s}$, followed by 30 cycles of denaturation at $94^{\circ} \mathrm{C}$ for $30 \mathrm{~s}$, annealing at $60^{\circ} \mathrm{C}$ for $30 \mathrm{~s}$, extension at $72^{\circ} \mathrm{C}$ for $60 \mathrm{~s}$, and final extension at $72^{\circ} \mathrm{C}$ for $300 \mathrm{~s}$; and set II has an initial heating at $95^{\circ} \mathrm{C}$ for $900 \mathrm{~s}$, followed by 30 cycles of denaturation at $94^{\circ} \mathrm{C}$ for $30 \mathrm{~s}$, annealing at $60^{\circ} \mathrm{C}$ for $90 \mathrm{~s}$, extension at $72^{\circ} \mathrm{C}$ for $90 \mathrm{~s}$, and final extension at $72^{\circ} \mathrm{C}$ for $600 \mathrm{~s}$. The PCR products are electrophoresed in $2 \%$ agarose gels using $1 \times$ TAE buffer, and stained with SYBR Safe DNA Gel stain (Invitrogen Japan K. K., Tokyo, Japan). The gels are photographed 


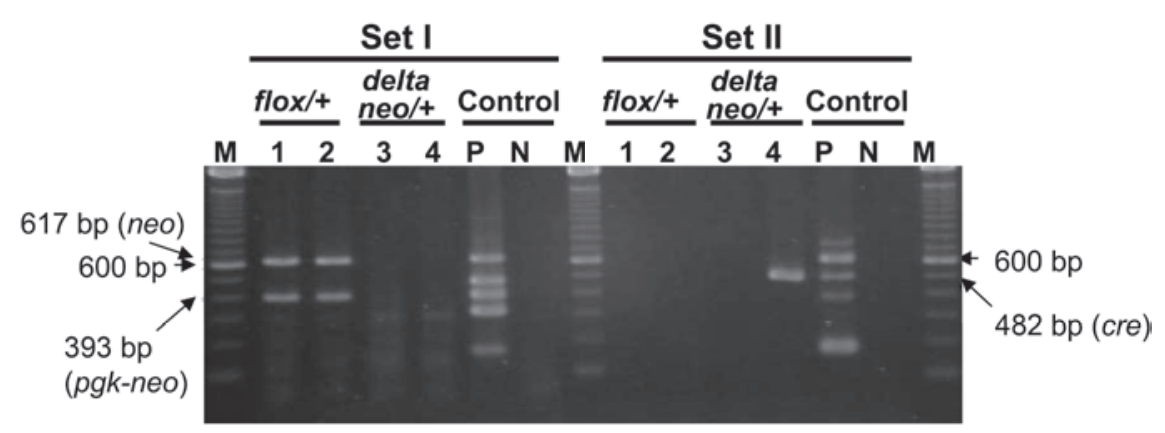

Fig. 2. Detection of pgk-neo and cre in conditional knockout mice by the KO-survey PCR. (A) Heterozygous ICR.Cg-Ripply $2^{\text {tmlYsa }}$ mice (flox/+, Nos. 1 and 2) carried a floxed allele containing a $p g k$-neo cassette. (B) Heterozygous Ripply $2^{\text {tml l.IYsa }} /+($ delta neo/+) descendants (Nos. 3 and 4) after crossing a heterozygous ICR.Cg-Ripply $2^{\text {tmlYsa }}$ mouse with a CAG-cre mouse to delete the floxed pgk-neo in the Ripply2 [17]. Lanes M, P, and $\mathrm{N}$ indicate DNA Marker (100 bp ladder), and positive and negative controls.

under UV light. The PCR products of the predicted sizes are shown as Figs. 1A and 1B.

Using the KO-survey PCR we screened 771 genetically-modified strains deposited at RIKEN BRC. The pgk-neo and HSV tk-neo promoter-selection marker gene cassettes were detected in $72(9.3 \%)$ and 32 (4.2\%) strains, respectively, the information for which did not contain $p g k$ and HSV $t k$ promoters. The following transgenes were not stipulated in the provided information, and were detected unexpectedly: cre and $f p$ recombinase genes in 24 strains (3.1\%), Gfp, lacZ, and other visualizing reporters in 9 strains (1.2\%). A total of 137 out of $771(17.8 \%)$ strains were found to have insufficient information about their genetic modifications, or had not been thoroughly examined in the course of establishing the strains by crossing with Cre-driver or GFP-reporter mice. Their genetic quality and relevant information must be improved prior to reproduction, preservation at our facility and distribution to users.

A typical example of detecting pgk-neo and cre in conditional knockout mice using the KO-survey PCR is shown in Fig. 2. Heterozygous ICR.Cg-Ripply2 $2^{\text {tm } 1 \text { Ysa }}$ $(f l o x /+)$ mice (Nos. 1 and 2, Fig. 2A) carried a floxed pgk-neo cassette in the Ripply2 [17]. We could detect cre in one of two descendants (Nos. 3 and 4, Fig. 2B) of heterozygous Ripply $2^{\text {tml.lYsa }} /+$ (delta neo/+) mice after deleting pgk-neo by crossing with a CAG-cre transgenic mice [20]. To establish a strain carrying Ripply $2^{\text {tml I.IYsa }}\left(\right.$ STOCK Ripply2 $2^{\text {tm I.IYsa }}$ ), the No. 3 mouse without cre was used for successive breeding, and the No. 4 mouse carrying cre was immediately eliminated from the colony.

Currently, a large number of reporter-null and conditional knockout mice are generated in international collaborations [6]. Multiple crosses among conditional knockout, tissue-specific Cre-driver and reporter strains are expected to increase tremendously in future functional genomics studies $[5,8,22]$. Consequently, RIKEN BRC as a dissemination center of mouse resources continues to pay much attention to the control of our genetic quality at every step from deposition, preservation and distribution of the strains. Depositor scientists are also requested to carefully screen every transgene in their genetically-modified strains prior to depositing the mice at RIKEN BRC.

In conclusion, the KO-survey PCR protocol enables us to cost-effectively screen 5 genes in one PCR tube, and to provide our users with mouse strains of the highest quality together with accurate information on their genetic modifications.

\section{Acknowledgment(s)}

We thank Drs. K. Moriwaki, K. Abe for valuable advice, and R. Kojima, F. Arai, M. Yamamoto, and M. Onuma, of the Experimental Animal Division, RIKEN BioResource Center for technical assistance. This study was conducted in cooperation with the NBRP of MEXT, Japan. 


\section{References}

1. Branda, C.S. and Dymecki, S.M. 2004. Dev. Cell 6: 7-28.

2. Brown, S.D., Hancock, J.M., and Gates, H. 2006. PloS Genet. 2: e118.

3. Bult, C.J., Blake, J.A., Richardson, J.E., Kadin, J.A., Eppig, J.T., Baldarelli, R.M., Barsanti, K., Baya, M., Beal, J.S., Boddy, W.J., Bradt, D.W., Burkart, D.L., Butler, N.E., Campbell, J., Corey, R., Corbani, L.E., Cousins, S., Dene, H., Drabkin, H.J., Frazer, K., Garippa, D.M., Glass, L.H., Goldsmith, C.W., Grant, P.L., King, B.L., Lennon-Pierce, M., Lewis, J., Lu, I., Lutz, C.M., Maltais, L.J., McKenzie, L.M., Miers, D., Modrusan, D., Ni, L., Ormsby, J.E., Qi, D., Ramachandran, S., Reddy, T.B., Reed, D.J., Sinclair, R., Shaw, D.R., Smith, C.L., Szauter, P., Taylor, B., Vanden Borre, P., Walker, M., Washburn, L., Witham, I., Winslow, J., and Zhu, Y. 2004. Nucleic Acids Res. 32: D476-481.

4. Capecchi, M.R. 1989. Science 244: 1288-1292.

5. Collins, F.S., Finnell, R.H., Rossant, J., and Wurst, W. 2007. Cell 129: 235.

6. Collins, F.S., Rossant, J., and Wurst, W. 2007. Cell 128: 9-13.

7. Datsenko, K.A. and Wanner, B.L. 2000. Proc. Natl. Acad. Sci. U.S.A. 97: 6640-6645.

8. Friedel, R.H., Seisenberger, C., Kaloff, C., and Wurst, W. 2007. Brief Funct. Genomic. Proteomic. 6: 180-185.

9. Furuta, Y., Lagutin, O., Hogan, B.L., and Oliver, G.C. 2000. Genesis 26: 130-132.

10. Giovannini, M., Robanus-Maandag, E., van der Valk, M., Niwa-Kawakita, M., Abramowski, V., Goutebroze, L., Woodruff, J.M., Berns, A., and Thomas, G. 2000. Genes Dev. 14: 1617-1630.

11. Han, H., Tanigaki, K., Yamamoto, N., Kuroda, K., Yoshimoto, M., Nakahata, T., Ikuta, K., and Honjo, T. 2002.Int. Immunol. 14: 637-645.

12. Iwasato, T., Datwani, A., Wolf, A.M., Nishiyama, H., Taguchi, Y., Tonegawa, S., Knopfel, T., Erzurumlu, R.S., and Itohara, S. 2000. Nature 406: 726-731.

13. Kanki, H., Suzuki, H., and Itohara, S. 2006. Exp. Anim. 55: 137-141.
14. Keng, V.W., Yae, K., Hayakawa, T., Mizuno, S., Uno, Y., Yusa, K., Kokubu, C., Kinoshita, T., Akagi, K., Jenkins, N.A., Copeland, N.G., Horie, K., and Takeda, J. 2005. Nat. Methods 2: 763-769.

15. Matsumura, H., Hasuwa, H., Inoue, N., Ikawa, M., and Okabe, M. 2004. Biochem. Biophys. Res. Commun. 321: 275-279.

16. McHugh, T.J., Jones, M.W., Quinn, J.J., Balthasar, N., Coppari, R., Elmquist, J.K., Lowell, B.B., Fanselow, M.S., Wilson, M.A., and Tonegawa, S. 2007. Science 317: 9499.

17. Morimoto, M., Sasaki, N., Oginuma, M., Kiso, M., Igarashi, K., Aizaki, K., Kanno, J., and Saga, Y. 2007. Development 134: 1561-1569.

18. Novak, A., Guo, C., Yang, W., Nagy, A., and Lobe, C.G. 2000. Genesis 28: 147-155.

19. Okabe, M., Ikawa, M., Kominami, K., Nakanishi, T., and Nishimune, Y. 1997. FEBS Lett. 407: 313-319.

20. Sakai, K. and Miyazaki, J. 1997. Biochem. Biophys. Res. Commun. 237: 318-324.

21. Sakaue-Sawano, A., Kurokawa, H., Morimura, T., Hanyu, A., Hama, H., Osawa, H., Kashiwagi, S., Fukami, K., Miyata, T., Miyoshi, H., Imamura, T., Ogawa, M., Masai, H., and Miyawaki, A. 2008. Cell 132: 487-498.

22. Schnutgen, F., De-Zolt, S., Van Sloun, P., Hollatz, M., Floss, T., Hansen, J., Altschmied, J., Seisenberger, C., Ghyselinck, N.B., Ruiz, P., Chambon, P., Wurst, W., and von Melchner, H. 2005. Proc. Natl. Acad. Sci. U.S.A. 102: 7221-7226.

23. Shen, Q., Sun, Q., Wei, X., Dong, J., Zhang, R., Wu, P., Jin, Y., Feng, J., Li, H., and Hu, Y. 2007. J. Biosci. Bioeng. 104: 14-21.

24. Takeuchi, T., Nomura, T., Tsujita, M., Suzuki, M., Fuse, T., Mori, H., and Mishina, M. 2002. Biochem. Biophys. Res. Commun. 293: 953-957.

25. Tonegawa, S., Nakazawa, K., and Wilson, M.A. 2003. Philos. Trans. R. Soc. Lond. B. Biol. Sci. 358: 787-795.

26. Yoshiki, A., Ike, F., Mekada, K., Kitaura, Y., Nakata, H., Hiraiwa, N., Mochida, K., Ijuin, M., Kadota, M., Murakami, A., Ogura, A., Abe, K., Moriwaki, K., and Obata, Y. 2009. Exp. Anim. 58: 85-96. 